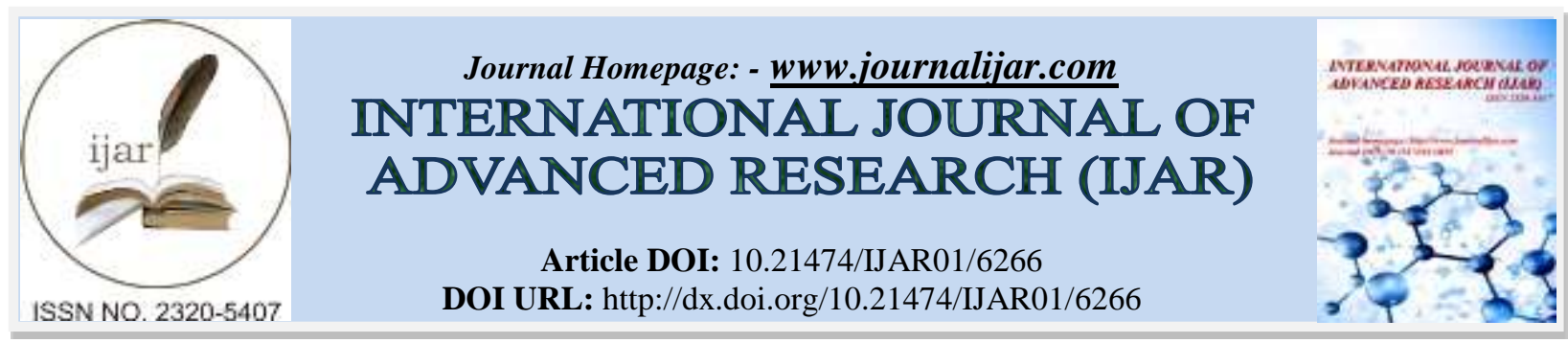

RESEARCH ARTICLE

\title{
VERRUCIFORM EPIDERMODYSPLASIA (STUDY OF 2 CASES) IN CHU MOHAMED V MARRAKECH MORROCCO.
}

Ouafaa Dhaidah, Moulay Driss Elamrani, Yassine Benchamkha and Salwa Ettalbi.

Department of Plastic and Reconstructive Surgery in CHU Mohamed VI, Marrakech, Morocco.

\section{Manuscript Info}

Manuscript History

Received: 10 November 2017

Final Accepted: 12 December 2017

Published: January 2018

Key words:-

Verruciform epidermodysplasia,

dermatology, oncology, plastic Surgery.

\begin{abstract}
Verruciform epidermodysplasia (VE) or Lutz-Lewandowski disease is a rare genodermatosis, most often autosomal recessive, characterized by abnormal susceptibility to infection by certain types of HPV. We report 2 cases with malignant transformation in squamous cell and basocellular carcinomas.

We study 2 cases of patients aged of 50 and 34 years old that suffer from this illness and have been received in plastic restorative and burns Department in CHU Mohamed V Marrakech Morocco.

In our study we try to focus on the origin, factors and the diagnostic of the Verruciform epidermodysplasia and compare them to those evocated by other authors and the treatment that has been followed.

Verruciform epidermodysplasia is a rare disease that requires early diagnosis to avoid the high potential for transformation for these patients.
\end{abstract}

Copy Right, IJAR, 2018,. All rights reserved.

\section{Introduction:-}

Verruciform Epidermodysplasia (EV) was described in 1922 by Lewandowski-Lutz[1]. It is a rare genodermatosis, with autosomal recessive inheritance, characterized by a facilitation of cutaneous infection by certain types of human papilloma virus (HPV) associated with a deficiency of cellular immunity [2,3]. We report two cases of EV associated with malignant transformation, specifying the clinical and evolutionary features of this condition through our observations and a review of the literature.

\section{Patients and observations:-}

Our study is retrospective about 2 cases collected from the plastic surgery; restorative and burns department, in Mohamed VI Hospital of Marrakech in Morocco, carriers of epidermodysplasue verruciform transformed into malignant tumors.

\section{Patient N: 1}

J.J is a woman aged 50 years, resulting from the first siblings cousins parents without pathological antecedents. The beginning of the symptomatology was at the age of 15 marked by the spontaneous appearance of the flat verrucous lesions disseminated all over the face; the trunk and limbs and generalized after all over the body with healthy skin intervals. The evolution was marked by the rapid appearance and increase of multiple tumors in 2 years (when she was 48 years old). The diagnosis of a verruciform epidermodysplasia was posed during her hospitalization in the dermatology department then sent to ours for additional care. On examination: achromatic warts and macules at the level of the face and the upper and lower limbs, with ulcero-budding tumors at the forehead, $8 \mathrm{~cm}$ long axis, another 
at the level of the internal cantus with a size of $2 \mathrm{~cm}$ and the third one was at the level of the external face of the leg with a size of $6 \mathrm{~cm}$.Biopsies were made for these 3 tumors under local anesthesia.The histological study has shown that it is a moderately differentiated squamous cell carcinoma. A cervicofacial CT is done as part of a local extension assessment showed a cutaneous process at the forehead, and opposite the root of the nose without invasive bone opposite. Tumor excision was made with margins of one centimeter for the tumor of the leg and the forehead and bone cut at the level of the latter for the tumor of the internal cantus of the eye and the septum was respected. The histological study showed epidermoid carcinoma at the three sites, with tumor limits at the level of the internal cantus (the patient refuses the ocular exenteration). A locoregional extension assessment was negative, the coverage made by a thin skin graft at the level of the loss of substance of the forehead and the leg was performed and for the internal cantus a cicatrization directed by Vaseline tulles and local topicals.

The patient was sent to the oncology department for additional care. They decided that radiotherapy is not recommended on the eye. Due to the ocular recurrence of the tumor; the patient accepted the ocular exenteration and readressed back to the oncology department for care.

\section{Patient 2:-}

O.Z patient, 34 years old woman with no pathological history; born of a consanguineous marriage, admitted to plastic, restorative and burns surgery department for a frontal tumor. The examination shows few warts on the face and limbs with an ulcero-budding tumor of 7 centimeters. The patient was operated several times; the pathological anatomy showed epidermoid carcinoma with a deep incomplete excision. Cervico-facial CT showed a tumor process of the left fronto-palpebral scalp without intracranial bone extension with infra-centimetric peripheral ganglia. A large surgical revision with ocular exenteration is done with coverage by a flap of the scalp. The patient was referred to the radiotherapy department where she did the sessions. Recurrence occurred after 6 months and cerebral CT showed cerebral parenchymal infiltration. A multidisciplinary staff (plastic surgery, dermatology, oncology and neurosurgery) decided on a tumor excision intraparechymate and covered by a free flap but due to the general deterioration, the treatment was palliative.

\section{Discussion:-}

LEWANDOWSKY-LUTZ disease is a rare condition. The evaluation of its frequency in the general population has rarely been done in the literature.

The small number of our observations does not allow us to draw a definitive conclusion on the average age of onset of the disease. All authors agree on the age of onset is in childhood, the age of malignant transformation for our population is after 30 years [4].

In the literature we do not note a predisposition of sex in disease, while in our population we find a female predominance [4].

The familial nature of the disease was recognized since S. HIDAKA (1924) who called it "verrucas dyskeratoticas congenitalis", It is a multifactorial disease involving genetic factors extrinsic (ultraviolet) and presumably immunological [ 5].

We find the hereditary character net in our cases. Indeed, Our patient N 2 had a deceased brother that had the same lesions as her. But at no time, none of our patients has reported a dermatitis concept to his parents. Note that in all our observations; we find a parental consanguinity [6,7].

We retain in our observations $50 \%$ of family cases. This is a high percentage compared to the literature which finds that vary between 10 and $20 \%[8,9]$.

The parental consanguinity of these cases is consistent with the literature that says that the mode of transmission is autosomal recessive and rarely the mode of transmission is recessive X-linked because in all our cases we do not find the same lesions among the ascendants.

The incidence of race seems relative. Our two patients belong to the brown race, recorded in North Africa zone (south of Morocco).Most cases of LEWANDOWSKY-LUTZ disease are white. SORYA ORGA MALIKI's study shows that there were five black patients in his study in Senegal. According to ANGO-PADONOU[9], the disease is 
ubiquitous without racial or geographic limitation, although the condition has rarely been described in black subjects.

The skin lesions are the cause of hospitalization for both patients. We generally find the same lesional aspects described in the literature. It is :

- Maculopapular lesions with warts. We note that these lesions are disseminated throughout the integument with healthy skin interval, small sizes with regular hypochromic contours or even non painful and itchy achromic.

- erythematous macular lesions of pityriasis versicolor almost are generalized to the entire hyperchromic integument and sometimes hypochromic. Diffuse and very squamous with bending folds.

- hyperpigmented palmoplantar keratotic lesions often found in the OS literature.

The histological examination was performed from biopsies or tumor excisions of cutaneous tissue fragment and allowed to find the characteristic lesions described by LEDERMAN which associates four signs in the histology of verruciform epidermodysplasia called hyperkeratosis, hyperacanthosis, hypergranulosis and intense vacuolar alteration in the center point which is the cytopathic effect of HPV viruses. This examination confirmed the diagnosis in all our patients who presented for the most part the characteristic signs of the histology of verruciform epidermodysplasia [10,11].

None of our two patients was able to benefit from genetic and biochemical studies or research of viral DNA. This would have been important. This is to know what type of HPV virus has infected each patient.

The small number of our observations does not allow us to draw a definitive conclusion on the average age of onset of the disease. All authors agree to locate the age of onset in childhoodIn the literature, we find this cancerization in 20 to $25 \%$ of cases - which is a very low rate compared to our patients who present $100 \%$ of malignant transformation found in basal cell carcinoma and squamous cell carcinoma that make all the seriousness of the disease [12].

The transformation into spino-cellular epithelioma after a rather long delay. Invasive cancer appears after 15 years, sometimes beyond 25 years, or even 40 years according to Lutzner. It is the possibility of this cancerous transformation that makes all of LEWANDOWSKY-LUTZ's disease. The age of malignant transformation for our population is after 30 years that is almost the same result found by other authors[13].

The prognosis of EV is related to the oncogenic potential of some HPV inducing carcinomas on the photo-exposed areas in 30 to $60 \%$ of cases [14].

We note the notion of recurrence with the appearance of other tumors despite an oncology surgical treatment associated with radiotherapy which makes the fatal prognosis of this pathology.

Patients must protect themselves from UV radiation at an early age. The retinoids, by their antiproliferative and inductive actions of the cellular differentiation, make it possible to prevent and to delay the occurrence of cutaneous cancers. They have only a partial effect on warts since keratinocytes are always infested with HPV. Their long-term use exposes them to the risk of side effects. Some tests based on interferon, vitamin D analogs and the combination of retinoic acid with interferon, give hope for a better therapeutic management of this ailment $[15,16]$.

\section{Conclusion:-}

EV is a rare genodermatosis. Its relationship with certain genetic diseases is well established. Our study of EV associated with a malignant transformation into cutaneous tumors that change the prognosis of this pathology. 


\section{Bibliography:-}

1. Ortak T, Uysal C A, AlagosMS, Orbay H, Sensoz O. Epidermodysplasia Verruciformis : An Unusual Presentation.

2. Dermatol Surg $2006 ; 32: 302-6$

3. Micalli G, Nasca MR, Dall'oglio F, Musumeci ML. Cimetine therapy for epidermodysplasia verruciformis. J Am Acad

4. Dermatol $2003 ; 48: 9-10$.

5. Weber BP, Fierlbeck G, Kempf HG. Multiple metachronous skin squamous cell carcinomas and epidermodysplasia

6. verruciformis in the head region : a human papillomavirusassociated disease. Eur Arch Otorhinolaryngol 1994 ; 3426.

7. DEGOS R .DermatologieEd. Med. Flammarion, Paris, 1981.

8. DESCAMPS V., BLANCHET-BARDON C., PETIT A., BACCARD M.,FISHER A., DUBERTRET L.

9. Epidermodysplasie verruciforme après greffe de moelle pour letraitement d'un déficit immunitaire combiné sévère : un modèle pourcomprendre le déficit immunitaire spécifique de l'E.V. ?Ann. Derm. Vénéreol., 1991, $118,847-850$.

10. 44- MATHIEU A., AVRIL M-F., DUVILLARD P., BLANCHET-BARDONC., ORTH G., BANANGER C., BOGNEL C., CHARPENTIER M.,GIRINSKY M.,PRADE M., LUBOINSKI B.Epidermodysplasie verruciforme et papillomavirus Présence d'HPV 5 dans une métastase ganglionnaire.Ann. Dermatol. Vénéréol., $1985,112: 741-742$

11. 50- PFISTER H.Human papillomavirus and impaired immunity epidermodysplasia

12. Verrucifonnis Arch. Derm. , 1987, $123: 1469-1470$

13. JABLONSKA S., OBALEK S., ORTH G., HAFTEK M.,CHORZELSKA M.J.

14. Regression of the lesions of epidermodysplasia verruciformis .Brit. J. Denn. 1982, 107 : 109-116

15. ANGOPADONOUF.,BOURLONDA.,MONTEIROB.,AMOUSSOUGNENOUD.,GNINAFON YEDOMON H., Epidennodysplasie verrucifonne : difficultés diagnostiques chez un sujetde race noire. Ann. Denn. Vénéréal.. 1990. 117 : 957-958.

16. CIVATTE J.Histopathologie cutanée. Ed. Med. Flammarion, Paris, 1967. 293

17. LEDERMAN D.P.Epidem10dysplasie verrucifom1e de Lewandowsky-Lutz. affection virale modèle de recherche sur l'action des virus à potentiel oncogène ;Med. et Hyg., 1981, 39 : 1576-1582.

18. DEGOS R., LEFORT P., BATISTA A.Epidermodysplasie verruciforme de Lewandowsky-LutzBull. Soc. Fr. Derm. Syph. 1957, $64: 278-279$.

19. JABLONSKA S., ORTH G.,Epiderrnodysplasia verruciforrnis.Clin. Derrn. 1980, $3: 83-86$

20. Lane JA, Bowman PH, Cohen DJ. Epidermodysplasia verruciformis. South Med J 2003 ; 96 : 613-5

21. Anadolu R, Oskay T, Erdem C, Boyvat A, Terzi E, Gürgey E.Treatment of epidermodysplasia verruciformis with acombination of acitretin and interferon alfa-2a. J Am Acad.Dermatol $2001 ; 45: 296-9$.

22. Junko Hi, Chihiro M, Tsuyoshi M, Makoto K,, Masaaki M.Treatment of localized epidermodysplasia verruciformis witht acalcitol ointment. Internat J Dermatology $2002 ; 41: 817-20$. 